\title{
Preparation of Light-Emitting Ytterbium-Doped Tantalum-0xide Thin Films Using a Simple Co-Sputtering Method
}

\author{
Kenta Miura*, Kazusa Kano, Yuki Arai, Osamu Hanaizumi \\ Graduate School of Science and Technology, Gunma University, Kiryu, Japan \\ Email: ${ }^{*}$ kkenta@gunma-u.ac.jp
}

Received 6 February 2015; accepted 13 February 2015; published 15 February 2015

Copyright (C) 2015 by authors and Scientific Research Publishing Inc.

This work is licensed under the Creative Commons Attribution International License (CC BY).

http://creativecommons.org/licenses/by/4.0/

\section{(c) (i) Open Access}

\begin{abstract}
Light-emitting ytterbium-doped tantalum-oxide thin films were prepared using a simple co-sputtering method for the first time. Sharp photoluminescence peaks having a wavelength of around $980 \mathrm{~nm}$ were observed from films annealed from $700^{\circ} \mathrm{C}$ to $1000^{\circ} \mathrm{C}$ for 10 to $40 \mathrm{~min}$. The strongest intensity of the $980-\mathrm{nm}$ peak was obtained from a film deposited using three ytterbium-oxide pellets and annealed at $800^{\circ} \mathrm{C}$ for $20 \mathrm{~min}$. Such rare-earth doped tantalum-oxide sputtered films can be used as high-refractive-index materials of autocloned photonic crystals that can be applied to novel light-emitting devices, and they will also be used as both anti-reflection and down-conversion layers for realizing high-efficiency silicon solar cells.
\end{abstract}

\section{Keywords}

Tantalum Oxide, Ytterbium, Co-Sputtering, Annealing, Photoluminescence

\section{Introduction}

Tantalum (V) oxide $\left(\mathrm{Ta}_{2} \mathrm{O}_{5}\right)$ is a high-refractive-index material used in passive optical elements such as $\mathrm{Ta}_{2} \mathrm{O}_{5} /$ $\mathrm{SiO}_{2}$ multilayered wavelength filters for dense wavelength-division multiplexing (DWDM). It has also been used as a high-index material of $\mathrm{Ta}_{2} \mathrm{O}_{5} / \mathrm{SiO}_{2}$ multilayered photonic-crystal elements for the visible to near-infrared range fabricated using the autocloning method based on radio-frequency (RF) bias sputtering [1]-[3], and it can additionally be used as an anti-reflection coating material for silicon solar cells [4]. However, $\mathrm{Ta}_{2} \mathrm{O}_{5}$ has recently attracted much attention as an active optical material, since broad red photoluminescence (PL) spectra at wavelengths from 600 to $650 \mathrm{~nm}$ were observed from thermal-oxidized amorphous $\mathrm{Ta}_{2} \mathrm{O}_{5}$ thin films [5]. In our previous work, we demonstrated blue PL from $\mathrm{Ta}_{2} \mathrm{O}_{5}$ thin films deposited by RF magnetron sputtering [6].

\footnotetext{
"Corresponding author.

How to cite this paper: Miura, K., Kano, K., Arai, Y. and Hanaizumi, O. (2015) Preparation of Light-Emitting YtterbiumDoped Tantalum-Oxide Thin Films Using a Simple Co-Sputtering Method. Materials Sciences and Applications, 6, $209-213$. http://dx.doi.org/10.4236/msa.2015.62024
} 
In addition, many studies on rare-earth-doped $\mathrm{Ta}_{2} \mathrm{O}_{5}$ have been conducted because $\mathrm{Ta}_{2} \mathrm{O}_{5}$ is a potential host material for new phosphors due to its low phonon energy $\left(100-450 \mathrm{~cm}^{-1}\right)$ compared with other oxide materials such as $\mathrm{SiO}_{2}$ [7]. We have reported on various rare-earth ( $\mathrm{Er}, \mathrm{Eu}, \mathrm{Tm}$, and $\mathrm{Y}$ ) doping into $\mathrm{Ta}_{2} \mathrm{O}_{5}$ thin films using simply co-sputtering of rare-earth oxide $\left(\mathrm{Er}_{2} \mathrm{O}_{3}, \mathrm{Eu}_{2} \mathrm{O}_{3}, \mathrm{Tm}_{2} \mathrm{O}_{3}\right.$, and $\left.\mathrm{Y}_{2} \mathrm{O}_{3}\right)$ pellets and a $\mathrm{Ta}_{2} \mathrm{O}_{5}$ disc [8]-[12]. Moreover, in our recent study, we fabricated $\mathrm{Er}, \mathrm{Eu}$, and Ce co-doped $\mathrm{Ta}_{2} \mathrm{O}_{5}\left(\mathrm{Ta}_{2} \mathrm{O}_{5}\right.$ : $\left.\mathrm{Er}, \mathrm{Eu}, \mathrm{Ce}\right)$ thin films using the co-sputtering method, and observed yellow PL from the films.

In this study, in order to expand the useful wavelength range of our $\mathrm{Ta}_{2} \mathrm{O}_{5}$-based light-emitting sputtered films, we fabricated ytterbium-doped $\mathrm{Ta}_{2} \mathrm{O}_{5}\left(\mathrm{Ta}_{2} \mathrm{O}_{5}: \mathrm{Yb}\right)$ thin films using the simple co-sputtering method for the first time.

\section{Experimental}

$\mathrm{Ta}_{2} \mathrm{O}_{5}: \mathrm{Yb}$ thin films were deposited using an RF magnetron sputtering system (ULVAC, SH-350-SE). A $\mathrm{Ta}_{2} \mathrm{O}_{5}$ disc (Furuuchi Chemical Corporation, 99.99\% purity, diameter $100 \mathrm{~mm}$ ) was used as the sputtering target. We placed $\mathrm{Yb}_{2} \mathrm{O}_{3}$ pellets (Furuuchi Chemical Corporation, 99.9\% purity, diameter $21 \mathrm{~mm}$ ) on the $\mathrm{Ta}_{2} \mathrm{O}_{5}$ disc. The $\mathrm{Ta}_{2} \mathrm{O}_{5}$ disc and $\mathrm{Yb}_{2} \mathrm{O}_{3}$ pellets were co-sputtered by supplying RF power to the target. Figure 1 is a schematic diagram of the sputtering target, with three $\mathrm{Yb}_{2} \mathrm{O}_{3}$ pellets on the $\mathrm{Ta}_{2} \mathrm{O}_{5}$ disc. We prepared co-sputtered $\mathrm{Ta}_{2} \mathrm{O}_{5}: \mathrm{Yb}$ films with different $\mathrm{Yb}$ concentrations by placing two, three, four, or five $\mathrm{Yb}_{2} \mathrm{O}_{3}$ pellets on the $\mathrm{Ta}_{2} \mathrm{O}_{5}$ disc. The flow rate of argon gas introduced into the vacuum chamber was $10 \mathrm{sccm}$, and the pressure in the chamber during deposition was kept at $\sim 1 \mathrm{~Pa}$. The RF power supplied to the target was $200 \mathrm{~W}$. Commercial fused silica plates (ATOCK Inc., $1 \mathrm{~mm}$ thick) were used as substrates. The substrates were not heated during sputtering. We subsequently annealed the samples in ambient air using an electric furnace (Denken, KDF S-70).

The PL spectra of the $\mathrm{Ta}_{2} \mathrm{O}_{5}: \mathrm{Yb}$ films were measured using a dual-grating monochromator (Roper Scientific, SpectraPro 2150i) and a CCD detector (Roper Scientific, Pixis: 100B, electrically cooled to $-80^{\circ} \mathrm{C}$ ). An He-Cd laser (Kimmon, IK3251R-F, wavelength $\lambda=325 \mathrm{~nm}$ ) was used to excite the films.

\section{Results and Discussion}

Figure 2 presents PL spectra of the $\mathrm{Ta}_{2} \mathrm{O}_{5}: \mathrm{Yb}$ films deposited using two, three, four, or five $\mathrm{Yb}_{2} \mathrm{O}_{3}$ pellets and annealed at $900^{\circ} \mathrm{C}$ for $20 \mathrm{~min}$. Intense PL peaks around a wavelength of $980 \mathrm{~nm}$ were observed from all of the samples. The 980-nm peaks seem to be the result of the ${ }^{2} \mathrm{~F}_{5 / 2} \rightarrow{ }^{2} \mathrm{~F}_{7 / 2}$ transition of $\mathrm{Yb}^{3+}$ [13]. The peak intensity once increased and subsequently decreased with increasing the number of $\mathrm{Yb}_{2} \mathrm{O}_{3}$ pellets (the $\mathrm{Yb}$ concentration) as [13]. Figure 2 indicates that the film deposited using three $\mathrm{Yb}_{2} \mathrm{O}_{3}$ pellets exhibited the strongest intensity of the 980 -nm peak after annealing at $900^{\circ} \mathrm{C}$ for $20 \mathrm{~min}$.

Figure 3 presents PL spectra from $\mathrm{Ta}_{2} \mathrm{O}_{5}: \mathrm{Yb}$ films deposited using the standard three $\mathrm{Yb}_{2} \mathrm{O}_{3}$ pellets and annealed at $900^{\circ} \mathrm{C}$ for $10,20,30$, or $40 \mathrm{~min}$. The 980 -nm-peak intensities from the samples annealed for 10,30 , and $40 \mathrm{~min}$ were approximately the same, but the peak intensity from the sample annealed for 20 min was stronger than the others. We therefore considered that the proper annealing time is $20 \mathrm{~min}$.

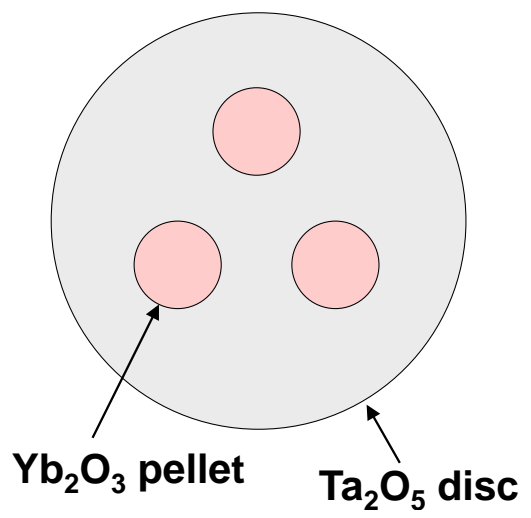

Figure 1. Schematic diagram of the sputtering target for simply co-sputtering of $\mathrm{Yb}_{2} \mathrm{O}_{3}$ and $\mathrm{Ta}_{2} \mathrm{O}_{5}$. 
Figure 4 presents PL spectra from $\mathrm{Ta}_{2} \mathrm{O}_{5}$ : $\mathrm{Yb}$ films deposited using the three $\mathrm{Yb}_{2} \mathrm{O}_{3}$ pellets and annealed at $700^{\circ} \mathrm{C}, 800^{\circ} \mathrm{C}, 900^{\circ} \mathrm{C}$, or $1000^{\circ} \mathrm{C}$ for the standard $20 \mathrm{~min}$. The 980 -nm-peak intensity once increased and subsequently decreased with increasing the annealing temperature. The strongest peak intensity was observed from the sample annealed at $800^{\circ} \mathrm{C}$. Interestingly, the PL peak observed from the sample annealed at $700^{\circ} \mathrm{C}$ was sharper than that of the other samples. From the X-ray diffraction (XRD) measurements, the sample annealed at $700^{\circ} \mathrm{C}$ seemed to be amorphous phase, and the samples annealed at $800^{\circ} \mathrm{C}, 900^{\circ} \mathrm{C}$, or $1000^{\circ} \mathrm{C}$ seemed to be polycrystalline phase. We will continue to investigate the relationship between the width of the 980 -nm peak and the crystallizability of our $\mathrm{Ta}_{2} \mathrm{O}_{5}: \mathrm{Yb}$ film.

\section{Conclusion}

$\mathrm{Ta}_{2} \mathrm{O}_{5}: \mathrm{Yb}$ thin films were prepared by our simple co-sputtering method for the first time, and PL spectra having sharp peaks at a wavelength of $980 \mathrm{~nm}$ were observed from the films after annealing from $700^{\circ} \mathrm{C}$ to $1000^{\circ} \mathrm{C}$ for 10 to 40 min. The reference conditions for fabricating our $\mathrm{Ta}_{2} \mathrm{O}_{5}: \mathrm{Yb}$ films (three $\mathrm{Yb}_{2} \mathrm{O}_{3}$ pellets; annealing temperature $800^{\circ} \mathrm{C}$; annealing time $20 \mathrm{~min}$ ) determined to provide the strongest PL peak intensity. Such rare-earth-

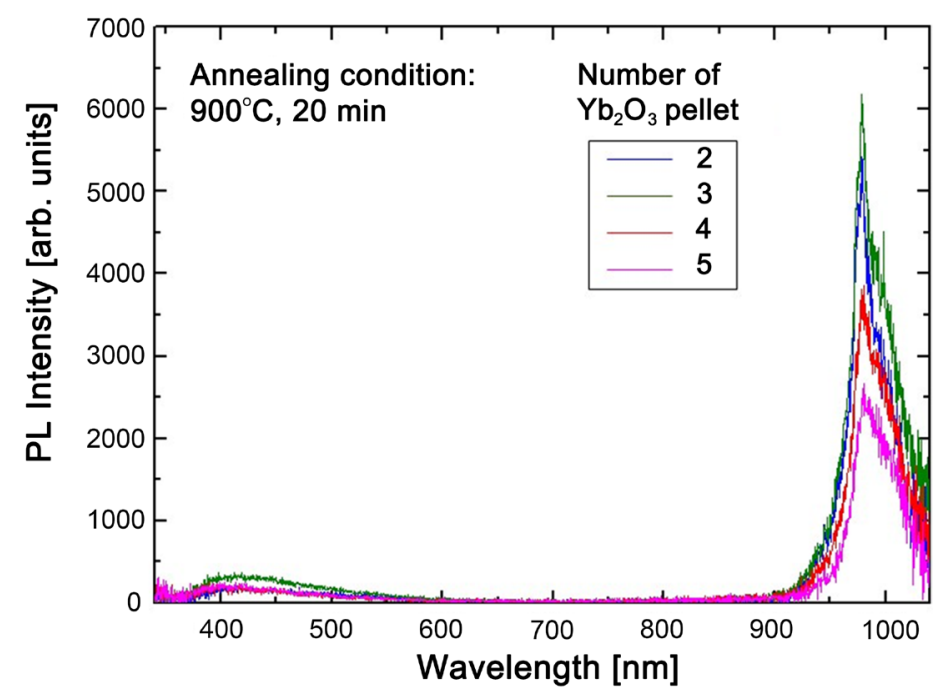

Figure 2. PL spectra of $\mathrm{Ta}_{2} \mathrm{O}_{5}: \mathrm{Yb}$ co-sputtered films deposited using two, three, four, or five $\mathrm{Yb}_{2} \mathrm{O}_{3}$ pellets and annealed at $900^{\circ} \mathrm{C}$ for $20 \mathrm{~min}$.

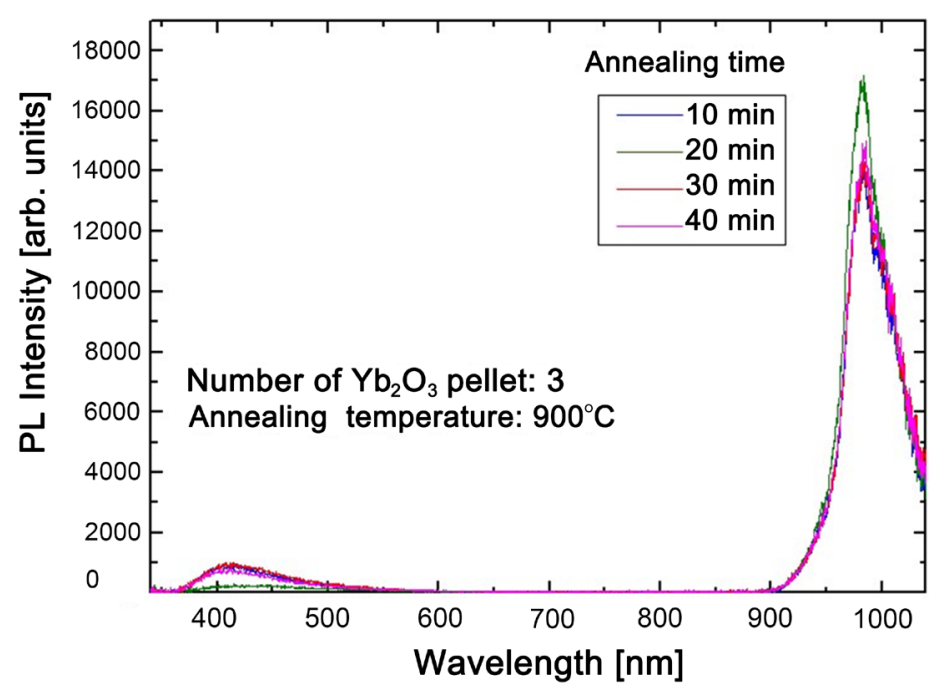

Figure 3. PL spectra of $\mathrm{Ta}_{2} \mathrm{O}_{5}: \mathrm{Yb}$ co-sputtered films deposited using three $\mathrm{Yb}_{2} \mathrm{O}_{3}$ pellets and annealed at $900^{\circ} \mathrm{C}$ for 10,20 , 30, or $40 \mathrm{~min}$. 


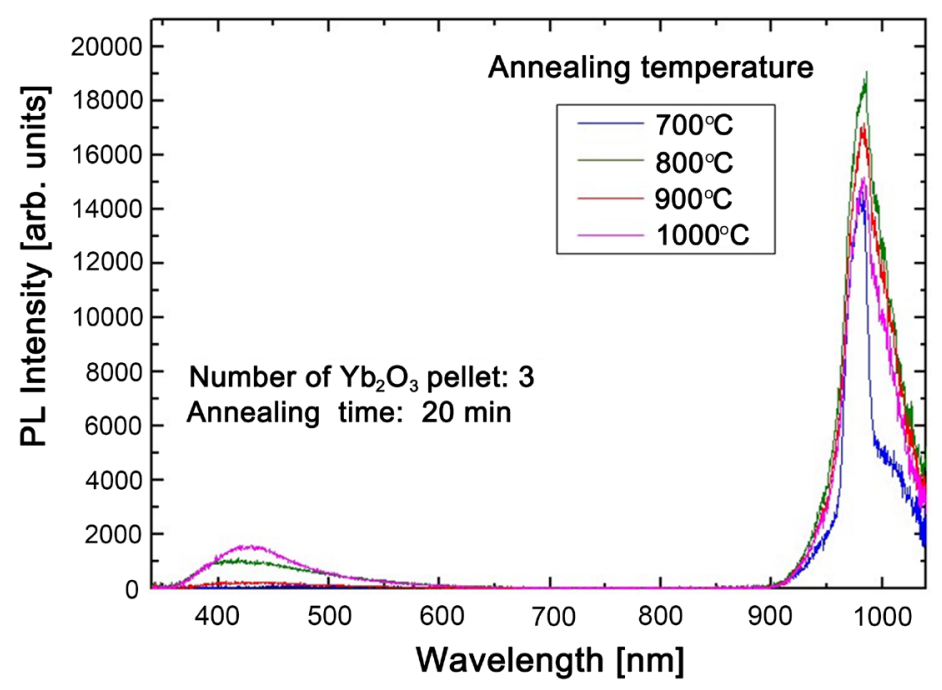

Figure 4. PL spectra of $\mathrm{Ta}_{2} \mathrm{O}_{5}: \mathrm{Yb}$ co-sputtered films deposited using three $\mathrm{Yb}_{2} \mathrm{O}_{3}$ pellets and annealed at $700^{\circ} \mathrm{C}, 800^{\circ} \mathrm{C}, 900^{\circ} \mathrm{C}$, or $1000^{\circ} \mathrm{C}$ for $20 \mathrm{~min}$.

doped $\mathrm{Ta}_{2} \mathrm{O}_{5}$ sputtered films can be used as high-refractive-index materials of $\mathrm{Ta}_{2} \mathrm{O}_{5} / \mathrm{SiO}_{2}$ autocloned (multilayered) photonic crystals that can be applied to novel light-emitting devices [1], and they will also be used as both anti-reflection [4] and down-conversion [13] [14] layers for realizing high-efficiency silicon solar cells.

\section{Acknowledgements}

This work was supported by the "Element Innovation” Project by Ministry of Education, Culture, Sports, Science and Technology in Japan; and JSPS KAKENHI Grant Number 26390073. Part of this work was conducted at the Human Resources Cultivation Center (HRCC), Gunma University, Japan.

\section{References}

[1] Hanaizumi, O., Miura, K., Saito, M., Sato, T., Kawakami, S., Kuramochi, E. and Oku, S. (2000) Frontiers Related with Automatic Shaping of Photonic Crystals. IEICE Transactions on Electronics, E83-C, 912-919.

[2] Sato, T., Miura, K., Ishino, N., Ohtera, Y., Tamamura, T. and Kawakami, S. (2002) Photonic Crystals for the Visible Range Fabricated by Autocloning Technique and Their Application. Optical and Quantum Electronics, 34, 63-70. http://dx.doi.org/10.1023/A:1013382711983

[3] Miura, K., Ohtera, Y., Ohkubo, H., Akutsu, N. and Kawakami, S. (2003) Reduction of Propagation and Bending Losses of Hetero-Structured Photonic Crystal Waveguides by Use of a High- $\Delta$ Structure. Optics Letters, 28, 734-736. http://dx.doi.org/10.1364/OL.28.000734

[4] Cid, M., Stem, N., Brunetti, C., Beloto, A.F. and Ramos, C.A.S. (1998) Improvements in Anti-Reflection Coatings for High-Efficiency Silicon Solar Cells. Surface and Coatings Technology, 106, 117-120. http://dx.doi.org/10.1016/S0257-8972(98)00499-X

[5] Zhu, M., Zhang, Z. and Miao, W. (2006) Intense Photoluminescence from Amorphous Tantalum Oxide Films. Applied Physics Letters, 89, Article ID: 021915. http://dx.doi.org/10.1063/1.2219991

[6] Miura, K., Miyazaki, H. and Hanaizumi, O. (2008) Observation of Blue-Light Emission from Tantalum Oxide Films Deposited by Radio-Frequency Magnetron Sputtering. IEICE Transactions on Electronics, E91-C, 1669-1672.

[7] Sanada, T., Wakai, Y., Nakashita, H., Matsumoto, T., Yogi, C., Ikeda, S., Wada, N. and Kojima, K. (2010) Preparation of $\mathrm{Eu}^{3+}$-Doped $\mathrm{Ta}_{2} \mathrm{O}_{5}$ Phosphor Particles by Sol-Gel Method. Optical Materials, 33, 164-169. http://dx.doi.org/10.1016/j.optmat.2010.08.018

[8] Singh, M.K., Fusegi, G., Kano, K., Bange, J.P., Miura, K. and Hanaizumi, O. (2009) Intense Photoluminescence from Erbium-Doped Tantalum Oxide Thin Films Deposited by Sputtering. IEICE Electronics Express, 6, 1676-1682. http://dx.doi.org/10.1587/elex.6.1676

[9] Singh, M.K., Miura, K., Fusegi, G., Kano, K. and Hanaizumi, O. (2013) Visible-Light Emission Properties of ErbiumDoped Tantalum-Oxide Films Produced by Co-Sputtering. Key Engineering Materials, 534, 154-157. 
http://dx.doi.org/10.4028/www.scientific.net/KEM.534.154

[10] Miura, K., Arai, Y., Osawa, T. and Hanaizumi, O. (2012) Light-Emission Properties of Europium-Doped TantalumOxide Thin Films Deposited by Radio-Frequency Magnetron Sputtering. Journal of Light and Visual Environment, 36, 64-67. http://dx.doi.org/10.2150/jlve.36.64

[11] Miura, K., Osawa, T., Yokota, Y., Suzuki, T. and Hanaizumi, O. (2014) Fabrication of Tm-Doped $\mathrm{Ta}_{2} \mathrm{O}_{5} \mathrm{Thin}_{\text {Films }}$ Using a Co-Sputtering Method. Results in Physics, 4, 148-149. http://dx.doi.org/10.1016/j.rinp.2014.08.011

[12] Miura, K., Osawa, T., Yokota, Y. and Hanaizumi, O. (2014) Fabrication and Evaluation of $\mathrm{Ta}_{2} \mathrm{O}_{5}: \mathrm{Y}_{2} \mathrm{O}_{3}$ Co-Sputtered Thin Films. Results in Physics, 4, 185-186. http://dx.doi.org/10.1016/j.rinp.2014.09.004

[13] Ueda, J. and Tanabe, S. (2011) Broadband near Ultra Violet Sensitization of $1 \mu \mathrm{m}$ Luminescence in $\mathrm{Yb}^{3+}-\mathrm{Doped} \mathrm{CeO}_{2}$ Crystal. Journal of Applied Physics, 110, Article ID: 073104. http://dx.doi.org/10.1063/1.3642984

[14] Rodriguez, V.D., Tikhomirov, V.K., Mendez-Ramos, J., Yanes, A.C. and Moshchalkov, V.V. (2010) Towards Broad Range and Highly Efficient Down-Conversion of Solar Spectrum by $\mathrm{Er}^{3+}-\mathrm{Yb}^{3+} \mathrm{Co}$-Doped Nano-Structured Glass-Ceramics. Solar Energy Materials and Solar Cells, 94, 1612-1617. http://dx.doi.org/10.1016/j.solmat.2010.04.081 
Scientific Research Publishing (SCIRP) is one of the largest Open Access journal publishers. It is currently publishing more than 200 open access, online, peer-reviewed journals covering a wide range of academic disciplines. SCIRP serves the worldwide academic communities and contributes to the progress and application of science with its publication.

Other selected journals from SCIRP are listed as below. Submit your manuscript to us via either submit@scirp.org or Online Submission Portal.
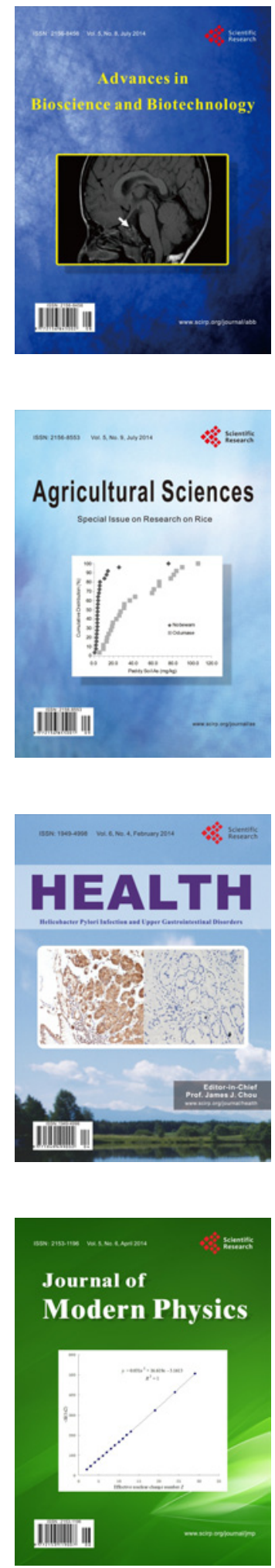
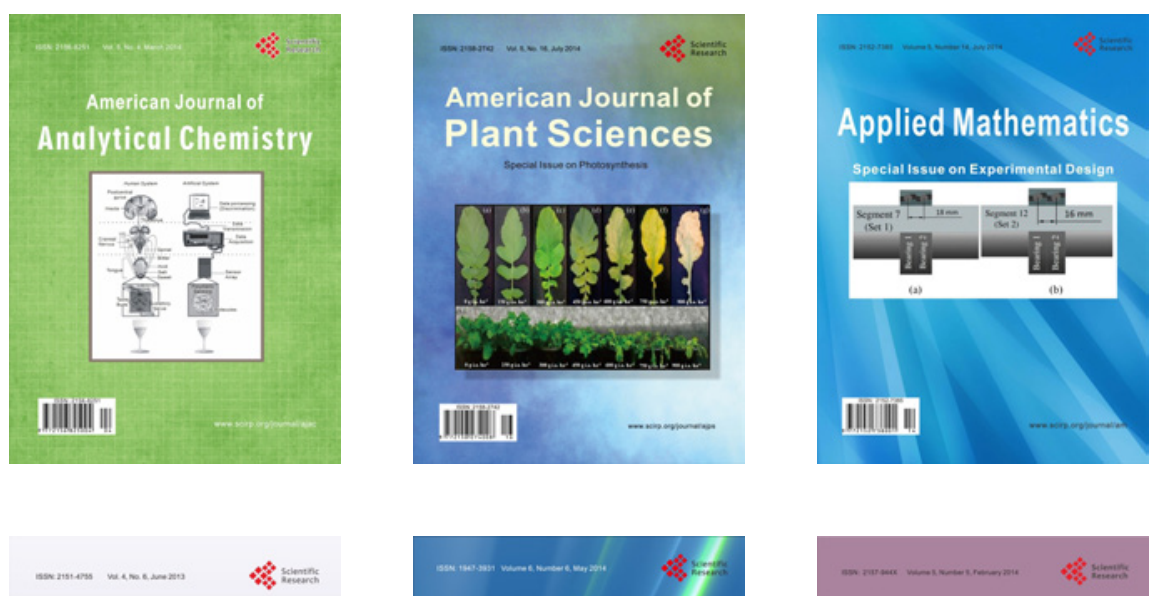

Creative Education
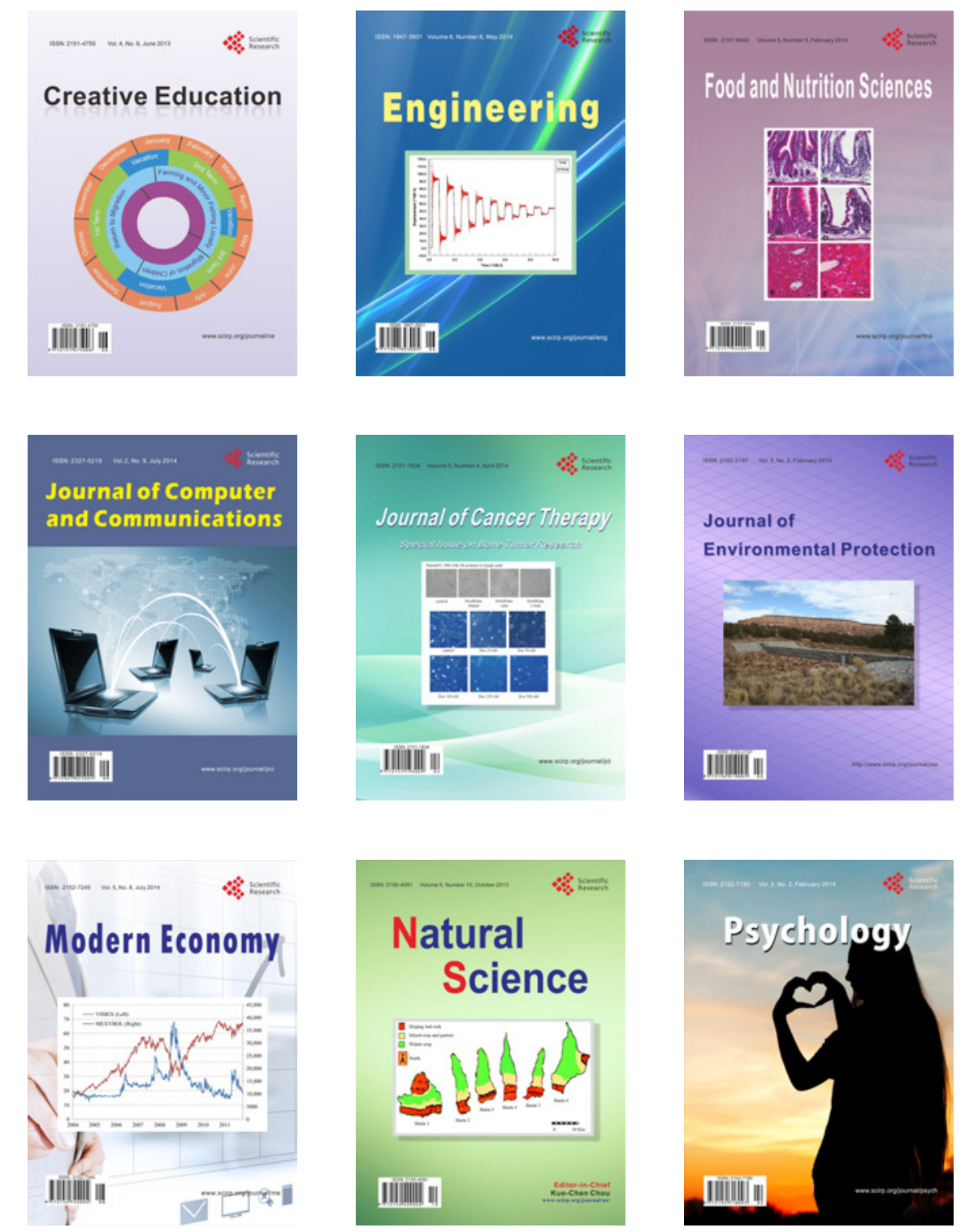